\title{
Determinants of Foreign Direct Investment in Egypt's Agriculture
}

\section{Kassem, A.Z. ${ }^{1}$ and Mai M. Awad ${ }^{2}$}

${ }^{1}$ Agricultural Planning and Development Dep., Institute of National Planning.

2 Industrial Planning and Development Dep., Institute of National Planning. Received on: $17 / 11 / 2019$

Accepted for publication on: 24/11/2019

\section{Abstract}

This paper aims to explore the determinants of Foreign Direct Investment (FDI) in the agricultural sector in Egypt on both the sectoral and national levels. The paper used quarterly series data from July 2008 to June 2018 for agricultural FDI in Egypt as dependent variable, and eleven macroeconomic and agricultural economics exogenous variables. Ordinary Least Squares (OLS) and Weighted Least Squares (WLS) regression techniques were employed. The paper results revealed that the most important determinants of FDI in Egypt's agriculture were the exchange rate of US\$, lending and discount given to economic sectors, and interest rate, in addition to the agricultural market size, main agricultural exports, and main agricultural imports. Data about water abundance, fiscal expenditure on agriculture and political stability index were not available to the authors at the time of the study in quarterly basis. Therefore, researchers are encouraged to consider them in further studies. The paper includes implications for attracting more FDI to the Egyptian agricultural sector via utilizing the positive impacts of the flotation of the Egyptian pound, the increased lending and discount given to the economic sectors and the current imports substitution policy on FDI in Egypt's agriculture. This paper contributes and fills the existence gab in the literature by providing empirical evidence on the determinants of agricultural FDI in Egypt.

Keywords: Agricultural FDI, FDI determinants, Agricultural sector, Egypt.

\section{Introduction}

Most of developing and developed countries consider FDI as a key factor for sustainable development. FDI is best explained as, "An investment involving a long-term relationship, and reflecting a lasting interest and control by a resident entity in one economy (foreign direct investor or parent enterprise) in an enterprise resident in an economy other than that of the foreign direct investor (FDI enterprise or affiliate enterprise or foreign affiliate" (UNCTAD, 2007). Global FDI flows decreased by $35 \%$ to 432 US\$ billion in the first half of 2018 , compared to the second half of 2017. The overall decrease was most- ly due to the effects of the US tax reform (OCED, 2018). Egypt considered as the top host economy for FDI in Africa in 2017 (UNCTAD, 2018). In Egypt, the total FDI at current prices in the financial year 2017/2018 estimated at 13.16 US\$ billion, while the net FDI at the same year was only 7.72 US\$ billion (CBE, 2019B).

The total FDI in Egypt at the current prices during the period from July 2008 to June 2016 on a quarterly base averaged about 2.95 US\$ billion. Total FDI recorded a minimum of 1.29 US\$ billion at the second quarter of the financial year 2011/2012, and a maximum of 4.64 US\$ billion in the fourth quarter of the financial year 
$2011 / 2012$, with a coefficient of variation reached about 23\% (Table A1; CBE, 2019A). The European Union was the main source of FDI inflows to Egypt with 7.95 US\$ billion, representing about $60.41 \%$ of FDI inflows in 2017/2018, while FDI inflows from USA and Arab countries accounted for $17.05 \%$ and $14.63 \%$ respectively of FDI inflows into Egypt in the same year (CBE, 2019A). The annual FDI directed to the Egyptian agricultural sector estimated at just 21.39 US\$ million on an average during the period from July 2008 to June 2018 (CBE, 2019B). Agricultural FDI in Egypt registered a minimum of only 0.2 US\$ million in the first quarter of the financial year 2012/2013, and a maximum of 249.6 US\$ million in the fourth quarter of the financial year 2008/2009, with a large coefficient of variation of 193\% (Table A1; CBE, 2019A).

FDI inflows into Egypt's agriculture is very low in comparison with other economic sectors. The oil sector was the most attractive for FDI, where $66.3 \%$ of total FDI in Egypt in July/March 2017/2018 targeted this crucial extractive sector, whereas FDI directed to the agricultural sector did not exceeded the limit of $0.1 \%$ at the same period (CBE, 2019B). This very low percentage of FDI that were attracted to the Egyptian agricultural sector may be a reflection of the increasingly low attention given to the agricultural sector in the last decade. Where the implemented investments in the agricultural sector estimated at $3.52 \%$ in average of the total implemented investments in Egypt during the period (2008 - 2018) (CAPMAS, 2019).
This paper aims at investigating the determinants of FDI in the agricultural sector in Egypt, on both the sectorial and national levels. The results of this paper will help policymakers in the Egyptian government in taking proper policies to attract and direct FDI towards the agricultural sector. Accordingly, the paper intends to answer, the main research question, which is: what are the determinants of FDI in the Egyptian agricultural sector? The rest of the paper is sectioned into five. Literature is reviewed in the second section. Third section describes the model, data sources and the estimation procedure. Forth section discusses the results. Conclusions and recommendations are briefed in the final section.

\section{Literature}

\subsection{Agricultural FDI determinants}

The determinants of inward FDI vary across countries, industries, and enterprises, but most of the available empirical studies have focused on the determinants of FDI at national or regional level. Studies at the industrial or sectoral level have been limited, especially the determinants of FDI in agricultural sector. Lv et al. (2010) included agricultural market size, agricultural exports, agricultural imports, agricultural markets opening, and industrial policy as the main exogenous variables affecting agricultural FDI. While Abdul Rashid et al. (2016) investigated the relationship between FDI in agriculture and macroeconomic factors, namely, exchange rate, inflation, poverty, infrastructure, business climate, and market size in selected high-income developing countries in Organization of 
Islamic Cooperation (OIC), namely: Malaysia, Oman, and Brunei.

At the national investment level in Egypt, Bassiony (2017) examined some related agricultural variables such as agricultural market size, agricultural imports, agricultural exports, agricultural wages, agricultural savings, agricultural fiscal expenditure, agricultural lending and discount, and interest rate on agricultural lending and discount as the potential determinants of FDI in the agricultural sector. Moreover, Mourao (2018) provided empirical evidence that population, forest area, exports diversification, and agriculture participation in GDP, inflation rates, real GDP per capita, government effectiveness, corruption perception, political stability, and regulatory quality were the economic factors that are determining the efficiency of Chinese's FDI in Africa.

\subsection{The most important FDI de- terminants}

Lv et al. (2010) found that the agricultural market size and agricultural imports were the most important factors in determining FDI inflows into china's agriculture. Abdul Rashid et al. (2016) stated that GDP and poverty were the most important factors in determining FDI in agricultural sector in Malaysia, Oman and Brunei. Bassiony (2017) demonstrated that the interest rate on agricultural lending and discount, gross agricultural wages, agricultural imports value, and agricultural exports value were the determining factors of agricultural investment in Egypt. Mourao (2018) indicated that dynamic national markets with a large population and significant forest area were the most preferred for the allocation of
Chinese FDI in 48 African countries between 2003 and 2010. Erdal and Tatoglu (2002) reported positive significant relationship between FDI and the domestic market size, infrastructure of the host country, and attractiveness of the host country's market, while they stated that exchange rate had insignificantly negative impact on FDI.

\subsection{Methods to estimate agricultur- al FDI models}

Lv et al. (2010) developed a multi-variate regression model that was employed to measure the relationship between FDI as a dependent variable and the selected explanatory variables during the period 19852016. Abdul Rashid et al. (2016) employed Pooled Ordinary Least Square (POLS) using a provisional panel data from 2003-2012 in selected highincome developing countries in Organization of Islamic Cooperation (OIS). Bassiony (2017) utilized the Ordinary Least Square (OLS) in regressing agricultural investment against selected explanatory factors, while Generalized Least Square (GLS) was employed, when the OLS results indicate the presence of autocorrelation accompanied with heteroscedasticity.

\section{Material and Methods \\ 3.1 Model}

In order to investigate the determinants of the FDI in Egypt's agriculture, the Ordinary Least Square (OLS) and Weighted Least Square (WLS) were employed to measure the relationship between FDI as a dependent variable and a set of agricultural and macroeconomic variables as explanatory variables using the quarterly data from July 2008 to June 
2018. Macroeconomic variables included total GDP at factor cost, inflation rate, exchange rate, interest rate, lending and discount for economic sectors, and economic sectors deposits. While Agricultural variables included agricultural market size, agricultural imports, agricultural exports, lending and discount for agricultural sector, and agricultural sector deposits.

Agricultural FDI inflows $=\beta 0+$ $\beta 1 G D P+\beta 2$ inflation rate $+\beta 3 E x-$ change rate $+\beta 4$ Interest rate $+\beta 5$ Economic sectors lending and discount $+\beta 6$ Economic sectors deposits $+\quad \beta 7$ Agricultural market size $+\beta 8$ Main agricultural exports $+\beta 9$ Main agricultural imports $+\beta 10$ lending and discount for agricultural sector + $\beta 11$ Agricultural sector deposits $+e$ Where:

- FDI= the agricultural FDI inflows

- $B 0=$ Intercept coefficient

- $\beta 1, \beta 2, \beta 3, \beta 4, \beta 5, \beta 6, \beta 7, \beta 8, \beta 9$, $\beta 10, \beta 11=$ Coefficients for each independent variable

\section{- $\quad e=$ residual term}

\subsection{Hypothesis}

Increased GDP associates with higher returns on investments and the potentiality of the economy and vice versa (Anna et al., 2012; Erdal and Tatoglu, 2002). The higher inflation rates are regarded as a sign of economic instability in the economy and this instability affect negatively the profitability of FDI (Anna et al., 2012). Phillips and Esfahani (2008) stated that different behavioral assumptions about FDI motive and investment environment have increased understanding of FDI-exchange rate link. Lily et al. (2014) argued that the currency appreciation of the host country increases FDI inflows, if the FDI objective is to serve the local market, but the relationship becomes negative, if the FDI objective is to reexport or reduce cost purpose. The more stable the currency of a country, the more likely that foreign firms will invest in that location (Chakrabarti, 2001; Erdal and Tatoglu, 2002).

Table 1. The study hypothesis

\begin{tabular}{|l|l|}
\hline$H 1$ & There is a significant positive relationship between GDP and the total agricultural FDI inflows. \\
\hline H2 & There is a significant negative relationship between the inflation rate and agricultural FDI inflows. \\
\hline H3 & There is a significant negative relationship between the exchange rate and agricultural FDI inflows. \\
\hline H4 & There is a significant negative relationship between the interest rate and FDI in the agricultural sector. \\
\hline H5 & There is a significant positive relationship between economic sectors lending and discount and total agricultural FDI inflows. \\
\hline H6 & There is a significant positive relationship between the economic sectors deposits and total agricultural FDI inflows. \\
\hline H7 & There is a significant positive relationship between the Agricultural market size and FDI in the agricultural sector. \\
\hline H8 & There is a significant positive relationship between the main Agricultural exports* value and FDI in the agricultural sector. \\
\hline H9 & There is a significant negative relationship between the main Agricultural imports** value and FDI in the agricultural sector. \\
\hline H10 & There is a significant positive relationship between agricultural sector lending and discount and total agricultural FDI inflows. \\
\hline H11 & There is a significant positive relationship between the agricultural deposits and total agricultural FDI inflows. \\
& * Fresh, chilled, or cooked vegetables, Fresh or dried fruits, potatoes, and raw cotton. ** Wheat, \\
& maize and raw cane sugar.
\end{tabular}

Siddiqui and Aumeboonsuke (2014) noted that there were controversial issues in relationship of interest rate, and inflation with FDI inflows, but their findings for Singa- pore and Malaysia did not support the ideas that low interest rates attract the FDI inflow. Anna et al. (2012) nevertheless, reported that a relatively high interest rate in a host country has a 
positive impact on inward FDI. However, the direction of the impact could be in a reverse if the foreign investors depend on host countries capital market for raising FDI fund.

Feldstein (1995) claimed that most American firms are more likely to borrow abroad to finance overseas assets than to finance domestic assets. As well, increased deposits mean increased savings, which in turn will be translated into lending and discount available for making new investments by the domestic and foreign investors. Hence, increased lending and discount given to domestic and foreign investors encourage them to invest more in the host country. In the same vein, Doaa and Yahia (2014) claimed that higher saving rates and increased deposits encourage agricultural investment in Egypt. Lv et al. (2010) and Mourao, (2018) provided empirical evidence that the larger the agricultural market size, the more FDI it will get and vice versa. From the prospective of international trade, increased exports in the host country indicate its high potentiality, where multinational enterprises have the capability to expand the markets of their products and services outside the host country's market frontiers to reach easily the home country and other countries (Lv et al., 2010; Bassiony, 2017). While, if the multinational enterprises encounter obstacles to penetrate the host country's market by exports due to trade barriers, their marketing strategies might be oriented to invest directly in that country, which means that FDI inflows will increase and vice versa ( $\mathrm{Lv}$ et al., 2010; Bassiony, 2017). From the foregoing, the study hypothesis can be specified as described in Table (1).

\subsection{Data resources}

The paper depended mainly on quarterly time series data, consists of forty quarters extracted from the publications issued by CBE, namely, External position of the Egyptian economy, and Monthly statistical bulletin during the period from July/September 2008 until April/June 2018. The variables were chosen based on the data availability taking into account the empirical literature.

\subsection{Estimation procedure}

In order to achieve the paper aims, the effect of the exogenous variables on agricultural FDI were modeled using (OLS) and (WLS) regression techniques in three separated econometric models. In model (1), the agricultural FDI were regressed against the macroeconomic independent variables only, in model (2), the agricultural FDI were regressed against the agricultural independent variables only, while in model (3), the agricultural FDI were regressed against the macroeconomic and agricultural independent variables together.

At the very early beginning of the analysis, (OLS) regression using the Statistical Package for the Social Sciences (SPSS) version 20 was applied on all the three models. But the whole model in case of models (2) and (3) were not significant, where normality distribution and variance homogeneity tests revealed the presence of non-normality, outliers, and the variance heterogeneity, which meant that simple OLS assumptions on the original data will lead to misleading results or may not be the best 
test available. Thus, Weighted Least Squares (WLS) regression was used instead, in which transforming the $Y$ or $\mathrm{X}$ data or using an alternative straight-line regression may provide a better analysis (Baltagi, 2011).

\section{Results and Discussions}

\subsection{Results of agricultural FDI models}

As shown in Table (2), the adjusted $\mathrm{R}^{2}$ for model (1) estimated at 0.22 , which means that $22 \%$ of the variation in the agricultural FDI is explained by the model using the independent variables. According to model (1), exchange rate of US\$, interest rate 1 year (corporate), and lending and discount given to economic sectors were the most important determinants of the agricultural FDI in Egypt. Likewise in mod- el (2), the adjusted $\mathrm{R}^{2}$ estimated at 0.241 , which is not different from the explanation of the same result in model (1). In model (2), there were just two determinants of the agricultural FDI, namely: total share of agricultural sector in GDP, and the main agricultural imports. Finally, in the third model as shown in Table (2), the adjusted $\mathrm{R}^{2}$ achieved a slight increase to reach 0.288 , which means that more related independent variables might be added in further researches to explain the remaining variation in the dependent variable. Model (3) indicated that the most important determinants of the agricultural FDI were exchange rate of US\$, economic sectors lending and discount, and the agricultural sector deposits. 
Table 2. Estimation Results

\begin{tabular}{|c|c|c|c|c|c|c|}
\hline \multirow[b]{2}{*}{ Variable/statistic } & \multicolumn{2}{|c|}{ Model (1) } & \multicolumn{2}{|c|}{ Model (2) } & \multicolumn{2}{|c|}{ Model (3) } \\
\hline & $\boldsymbol{\beta}_{\text {Standardized }}$ & SE & $\bar{\beta}$ Standardized & SE & $\boldsymbol{\beta}_{\text {Standardized }}$ & SE \\
\hline Constant & -58.82276 & 128.84509 & 60.06934* & 24.33769 & -52.29176 & 73.02434 \\
\hline GDP at factor cost Total & 0.09393 & 0.00186 & -- & -- & -0.41915 & 0.00089 \\
\hline Core inflation & -0.29774 & 86.83623 & -- & -- & -0.80486 & 0.00263 \\
\hline Exchange Rate of US\$ & $3.84801 * *$ & 15.28477 & -- & -- & $8.43926^{*}$ & 7.21001 \\
\hline Interest rate 1 year (corporate) & $-2.28012 * *$ & 12.06372 & -- & -- & -3.82628 & 6.65437 \\
\hline \begin{tabular}{|lll}
$\begin{array}{l}\text { Economic sectors lending and } \\
\text { discount }\end{array}$ & & \\
\end{tabular} & $0.95797^{*}$ & 0.00353 & -- & -- & $2.56373^{*}$ & 0.00159 \\
\hline Economic sectors deposits & -1.802391 & 0.00118 & -- & -- & -1.83734 & 0.00046 \\
\hline $\begin{array}{l}\text { Share of agricultural sector in } \\
\text { GDP }\end{array}$ & -- & -- & $2.30326^{*}$ & 0.00125 & 0.04022 & 0.00263 \\
\hline Main agriculture Exports & -- & -- & -0.81622 & 0.01993 & $-0.78099 *$ & 0.05532 \\
\hline Main agriculture Imports & -- & -- & $-1.63336^{*}$ & 0.01143 & 0.02415 & 0.01647 \\
\hline \begin{tabular}{|l|} 
Agricultural sector Loans \\
\end{tabular} & -- & -- & 0.38633 & 0.01293 & -0.21478 & 0.02464 \\
\hline Agricultural sector Deposits & -- & -- & -0.37706 & 0.00960 & 0.125129 & 0.02242 \\
\hline R square & \multicolumn{2}{|c|}{0.340} & \multicolumn{2}{|c|}{0.338} & \multicolumn{2}{|c|}{0.489} \\
\hline Adjusted R ${ }^{2}$ & \multirow{2}{*}{\multicolumn{2}{|c|}{$\frac{0.220}{2837}$}} & \multicolumn{2}{|c|}{0.241} & \multicolumn{2}{|c|}{0.288} \\
\hline F-statistic & & & & & 2.4 & \\
\hline Probability for F-statistic & \multicolumn{2}{|c|}{0.024} & \multicolumn{2}{|c|}{0.012} & \multicolumn{2}{|c|}{0.028} \\
\hline
\end{tabular}

Notes:

- $\quad *, * *$ Statistical significance at 1 and 5 per cent probability level respectively.

- $\quad$ The results are calculated by SPSS version 20.

- All values are at current prices during the period (July 2008 - June 2018) (US\$ million) Source: Table A1.

\subsection{Further discussions based on the empirical results}

The study results agreed that there were six main determinants of agricultural FDI in Egypt, which were the exchange rate of US\$, economic sectors lending and discount, interest rate 1 year (corporate), share of agriculture in GDP as a proxy of the agricultural market size, main agricultural imports, and main agricultural exports. While five independent variable were not affecting significantly agricultural FDI in case of Egypt, namely GDP, core inflation, agricultural sector lending and discount, economic sectors lending and discount, and agricultural sector deposit.

The exchange rate of US\$ was statistically significantly impacted FDI into agriculture positively in both models (1) and (3) at least at 5 per- cent probability level, which is inconsistent with the study hypothesis (H3) that assumed a negative relationship between exchange rate and agricultural FDI, but this result is consistent with Abdul Rashid et al. (2016). This result is meeting one of the most important goals of the flotation of the Egyptian pound on November $3^{\text {rd }}$ 2016 by CBE, nevertheless the opposite effects of the flotation on the living standards of a large segment of the population. This positive relationship may point to that the FDI objective in the Egyptian agricultural sector is to re-export or reduce cost purpose (Lily et al., 2014). Meanwhile, as shown in table (2) Lending and discount given to the economic sectors were affecting agricultural FDI significantly in both models (1) and (3) at 5 percent probability level. The sign of the coefficient was positive as 
expected in the study hypothesis (H5), which indicated that the more lending and discount given to the economic sectors, the more attraction for foreign direct investment, as well as in the case of agricultural sector in Egypt.

Model (1) revealed that interest rate exerted a significantly negative effect on agricultural FDI in Egypt at 1 percent probability level, the negative sign of the coefficient was consistent with what was expected in the study hypothesis (H4). Hence, the relatively high interest rate $(12.68 \%$ one year- in average during the last decade) impede foreign direct investment. As model (2) pointed, share of agriculture in GDP as proxy of the agricultural market size had a statistically positive effect on agricultural FDI, as expected in the study hypothesis (H7). More attention to increase the agricultural production and productivity via increasing the implemented investments in Egypt's agriculture sector is needed to attract more FDI inflows.

Model (3) revealed that the main agricultural exports (Fresh, chilled, or cooked vegetables, Fresh or dried fruits, potatoes, and raw cotton) had statistically significantly impacted agricultural FDI negatively, but this is not complied with the study hypothesis (H8) that proposed the sign direction to be in a reverse. This unexpected result can be attributable to the degree of processing of the agricultural goods exported, where in this study the main raw agricultural exports were inclusively included in the model. And this means that, the less processing is the agricultural exports, the less attrac- tion to FDI in the agricultural sector. Model (2) as well reported that the imports of the main agricultural products (wheat, maize and raw cane sugar) had a statistically significant negative impact on agricultural FDI, and this is agreed with the study expectation in hypothesis (H9). Therefore, substitution policy of agricultural import is a vital tool to raise the attraction of more FDI into Egypt's agriculture.

\section{Conclusions and recommenda- tions:}

In light of the availability of data, eleven macroeconomics and agricultural factors were examined to test whether they were affecting the agricultural FDI in Egypt. It can be concluded that macroeconomic and sectorial variables were together responsible for the variation in FDI inflows into Egypt's agriculture. The most important determinants of the agricultural FDI in Egypt were the exchange rate of US\$, economic sectors lending and discount, and interest rate, in addition to other three determinants, which were the agricultural market size, main agricultural imports, and main agricultural exports. Indeed, proper decisions are needed to encourage the foreign investors to come and invest in this vital economic sector, and help in increasing capital formation rates and the Egyptian agricultural GDP.

In light of this paper's results, it is obviously declared that, the monetary policy tools come at the first priority of FDI in the agricultural sector in Egypt in terms of exchange rate of US\$, interest rate, and economic sectors lending and discount. The flotation of the Egyptian pound is working 
as an effective tool to attract FDI, especially with the expectation that the foreign investors in the Egyptian agriculture are aiming mainly at reducing the cost or re-exporting their products. Thus, policies for eliminating the operation costs in terms of energy, water, and skilled labors, as well as facilitating the export procedures are recommended incentives to attract more FDI to the agricultural sector. Raising interest rate as a tool of controlling inflation is considered a serious repel factor for FDI, so targeting lower interest rate in the medium term is highly recommended to transfer more foreign investment from indirect to direct forms. As well, providing more lending and discount to economic sectors seems to be an attractive tool for FDI in agricultural sector.

Innovative tools for booming the agricultural production via providing technical assistance, in order to increase the competitiveness of the local agricultural producers. This will not help only in meeting the increased demand on food locally, enhancing the external position of the Egyptian economy via adjusting the trade balance by more exports, but also it will captivate more FDI in the agricultural sector.

On the imports side, the current policy of substituting more imports by local alternatives could help in directing foreign investors to the agricultural sector to pursue their share in the Egyptian market by direct investment. Finally, the paper concluded that, the less processing is the agricultural exports, the less attraction to FDI in the agricultural sector. Thus, a policy for raising the export- ed volumes of non-raw agricultural products would work as an attractive tool for more FDI in the agricultural sector.

\section{References}

Abdul Rashid, I.M., Abu Bakar, N. and Abdul Razak, N.A. (2016). "Determinants of foreign direct investment (FDI) in agricultural sector based on selected high income developing economies in OIC countries: an empirical study on the provincial panel data by using STATA, 2003-2012", in IACOB, A. (Ed.), Procedia Economics and Finance 39 (2016) proceeding of the 3rd global conference on business, economics, management and tourism, 26-28 November 2015, Rome, Italy, Elsevier, Amsterdam, pp. $328-334$.

Baltagi, B.H. (2011). Econometrics, Springer, New York.

Bassiony, H.E.M. (2017). "Analytical Study of the Determinants of National and Agricultural Investment Efficiency in Egypt", Journal of Agricultural and Environmental Sciences, Vol. 2 Issue 16, pp. 3164.

CAPMAS (2019). available at: https://www.capmas.gov.eg, (accessed 11 January 2019).

Central Bank of Egypt (CBE) (2019A)."Monthly Statistical Bulletin", available at:

https://www.cbe.org.eg/ar/EconomicRes earch/Publications/Pages/Monthly StatisticaclBulletin.aspx , (accessed 11 January 2019).

Central Bank of Egypt (CBE) (2019B). "External Position of the Egyptian Economy", available at: https://www.cbe.org.eg/ar/Econom icResearch/Publications/Pages/

ExternalPosition.aspx, (accessed 11 January 2019).

Chakrabarti, A. (2001). "The Determinants of Foreign Direct Invest- 
ment: Sensitivity Analyses of Cross-Country Regressions", KYKLOS, Vol. 54 No. 1, pp. 89114.

Doaa, M.M. and Yahia, A.Y. (2014). "Econometric Analysis of Agricultural Investment in Egypt", Egyptian Journal of Agricultural Research, Vol. 92 No. 3, pp. 11751206.

Feldstein, M.S. (1995). "The Effects of Outbound Foreign Direct Investment on the Domestic Capital Stock", in Feldstein, M.S. (Ed.), "The Effects of Taxation on Multinational Corporations", University of Chicago Press, Chicago, pp.4366.

Erdal, F. and Tatoglu, E. (2002). "Locational Determinants of Foreign Direct Investment in an Emerging Market Economy: Evidence from Turkey", Multinational Business Review, Vol. 10 No.1, pp. 21-27.

Lily, J. et al. (2014). "Exchange Rate Movement and Foreign Direct Investment in Asean Economies", Economics Research International, Vol. 2014, pp. 1-10.

Lv, L., Wen, S. and Xiong, Q. (2010). "Determinants and performance index of foreign direct investment in China's agriculture", China Agricultural Economic Review, Vol. 2 Issue 1, pp. 36-48.
Mourao, P.R. (2018). "What is China seeking from Africa? An analysis of the economic and political determinants of Chinese Outward Foreign Direct Investment based on Stochastic Frontier Models", China Economic Review, Vol. 48, pp. 258-268.

Organization for Economic Cooperation and Development (OCED) (2018), FDI in figures, Paris.

Phillips, S. and Esfahani, F.Z.A. (2008). "Exchanges rates and foreign direct investment: theoretical models and empirical evidence", The Australian Journal of Agricultural and Resource Economics, Vol. 52, pp. 505-525.

Siddiqui, H.A.A. and Aumeboonsuke, V. (2014). "Role of Interest Rate in Attracting the FDI: Study on Asian 5 Economy", International Journal of Technical Research and Applications, Vol. 2 special issue 3, pp. 59-70.

UNCTAD (2007). World Investment Report 2007; Transitional Corporation, Extractive Industries and Development, United Nations, New York, NY and Geneva.

UNCTAD (2018). World Investment Report 2018: Investment and New Industrial Policy, United Nations, New York, NY and Geneva. 
محددات الاستثمار الأجنبى المباشر فى الزراعة المصرية

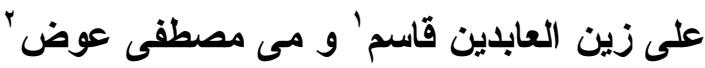

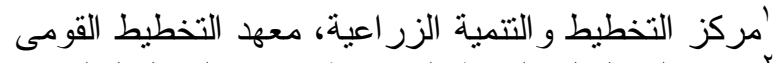

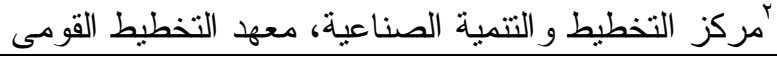

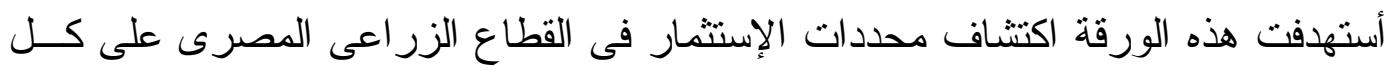

الملخص

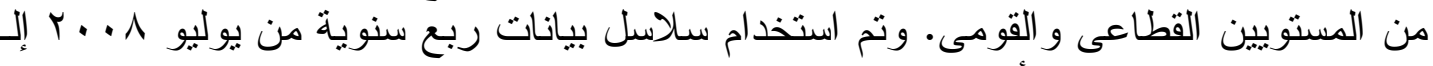

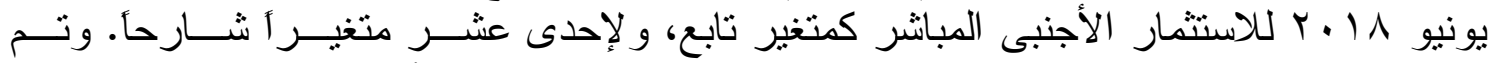

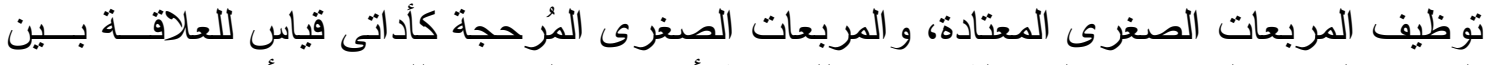

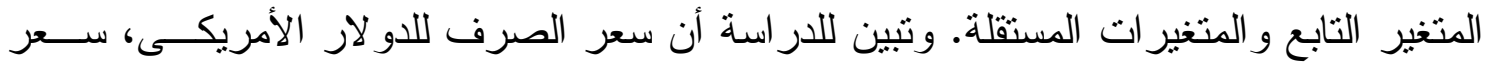

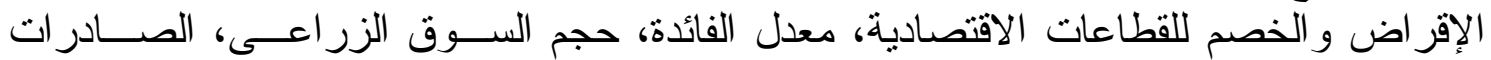

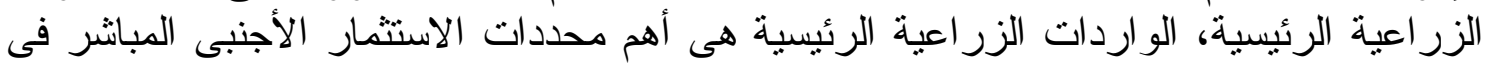

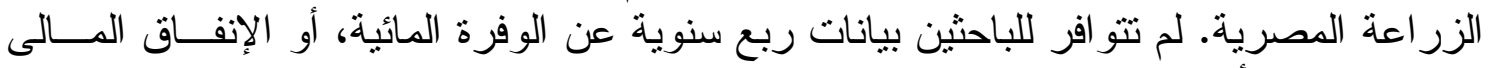

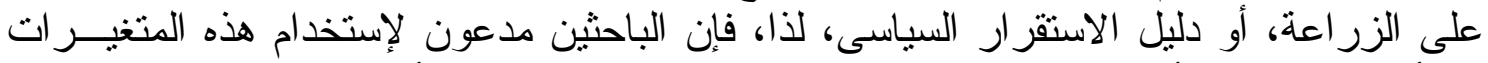

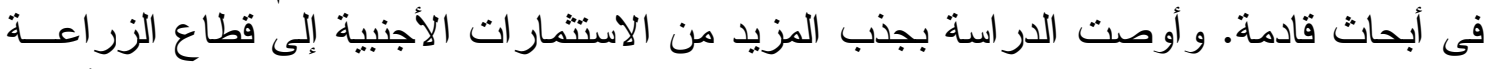

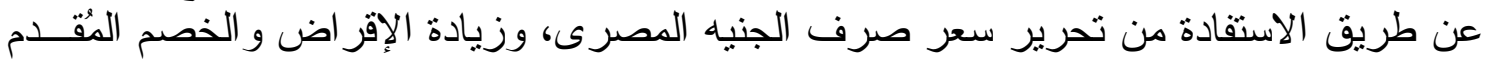

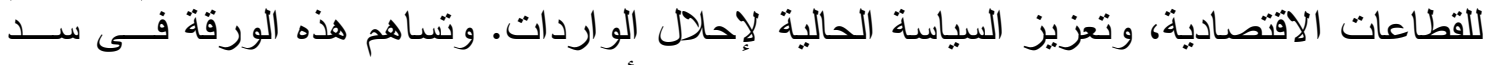

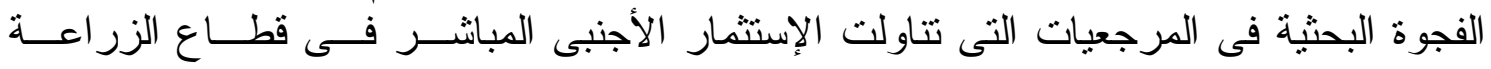
المصري، وتعريف محدد اتهـ. الكمات اللدالة: الاستثمار الأجنبى المباشر فى الزر اعة، الاستثمار الأجنبى المباشر، الزر اعة المصـرية، 